\title{
Säält ma lö̈̈dse luidsõ lutu ehk Hiiumaal elava võrukesest pärimusekandja Laine Mägi regilauludest ja enesemääratlusest
}

\author{
Helen Kõmmus
}

\begin{abstract}
Teesid: Tutvustan oma artiklis aastatel 2004-2007 Hiiumaal läbiviidud rahvaluule kogumise käigus võru päritolu laulikult Laine Mägilt talletatud salvestusi ja kirjalikke mälestusi. Informandi mälus on lisaks muule pärimusele viisteist vanemat ja uuemat rahvalaulu, nende hulgas ka mõned võrukeelsed regilaulud. Vaatlengi artiklis lähemalt kolme temalt kogutud regilaulu nii rahvalaulu vormi, murdekeele kui ka esitaja eluloolisest ja sotsiaalsest kontekstist lähtuvalt.
\end{abstract}

Märksõnad: rahvaluule kogumine, rahvalaul, regilaul, võru keel, võru kultuur

Regilaulu peetakse valdaval osal Eesti aladel nüüdseks elavast käibest taandunud pärimuseks. ${ }^{1}$ Sellest hoolimata kogutakse rahvasuust ikka veel värsi- ja viisikatkeid, hea õnne korral leitakse ka terviklikke regilaule.

2004. aasta novembris õnnestus mul rahvamuusika kogumisretkel Hiiumaal Pühalepa kihelkonnas Kärdlas kohtuda võrukesest pärimusetundja Laine Mägiga. Järgmise kolme aasta kestel toimunud kokkusaamised kujunesid huvitavaks välitöösarjaks. Talletasin informandilt viis ja pool tundi heli- ja videosalvestusi, käsikirjalise biograafia, laulutekste ja 12 fotot. ${ }^{2}$ Nüüdseks ligi pool sajandit Hiiumaal elanud kooliõpetaja pärimusmälus on lisaks rahvalauludele muinasjutte, naljandeid, ütlusi, mängu- ja tantsukirjeldusi.

Olen pärimusjuhilt talletanud viisteist vanemat ja uuemat rahvalaulu, mille hulgas on ka mitmeid võrukeelseid regilaule. Käesolev artikkel käsitleb Laine Mägilt kogutud vanemat lauluvara. Keskendun kolmele regilaulule, analüüsides neid nii laulu vormireeglite kui ka murdekeele seisukohalt. Samuti uurin lauluvara lähtuvalt esitaja eluloolisest ja sotsiaalsest kontekstist.

\section{Keel kui enesemääratuse alus}

Laine Mägi, neiupõlvenimega Lepla, sündis 1932. aastal Petserimaal Vilo vallas Ruuda jõe äärses Ruuda külas (vt kaarti). See oli võrukeste küla setukeelsel asualal, umbes 7 kilomeetrit Pankjavitsast kagu poole. Vastseliina kandist 


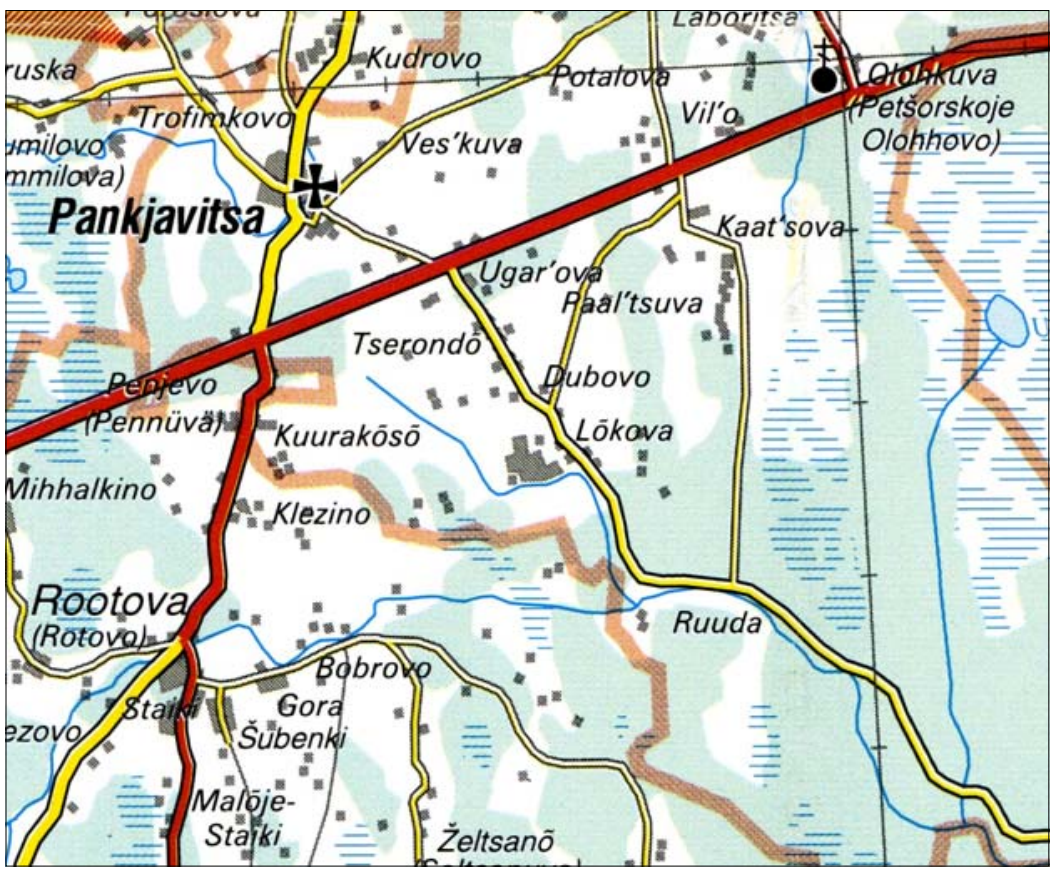

Kaart. Petserimaa kaart, Ruuda küla asukoht (Regio 1999).

tulnud isapoolsed vanavanemad ostsid Ruudale talukrundi umbes 1886 . aastal. Emapoolsed sugulased olid pärit Rõuge kihelkonnast. Ruudal möödusid informandi lapsepõlv ja esimesed kooliaastad. Keskkooli lõpetas ta Petseris.

Hiiumaale sattus Laine Lepla 1956. aastal pärast Tartu Õpetajate Seminari vene keele osakonna lõpetamist ametialase suunamisega. Esmalt oli ta vene keele õpetaja Lauka koolis, siis kuni pensionile jäämiseni Kärdla keskkooli õpetaja. Hiiumaalt leidis ta endale abikaasa ja siin sündisid lapsed.

Informandi praeguseks koduseks keeleks on küll eesti ühiskeel, ent võrukeelsest vanematekodust päritud emakeel on tal meeles ja südames. Meie vestlused kujunesid ajapikku aina võrukeelsemaks. Oma elu- ja perekonnaloo eelistas Laine Mägi panna paberile siiski kirjakeeles, kuna oli võru keelt kogenud ainult suulises kasutuses.

Mina olen pü̈̈dnud oma armast emakeelt alal hoida omal moel, hoida kõike seda, mida nägin ja kogesin lapsepõlves, oma kodukülas Ruudas. [---] Kuigi olen 50 aastat Hiiumaal elanud, austan ma oma mälestustes oma vanemaid ja nende kombeid ja keelt. Mina kui võsu nende kännust olen ikka võrumeelne ja -keelne (Laine Mägi, käsikiri 15. 09. 2006 Kärdla, lk 2. Siin ja edaspidi on informandi kirjaviis esitatud muutmata kujul). 
Kirjakeele eelistamisest hoolimata tuleb Laine Mägi mälestustes tihti ette meeleolukaid ja mahlakaid murdekeelseid ütlemisi:

Naaberküla setud ütlesid meie kohta "Tšuhkna, tšort, piimapört, hapnõpiimä hapatus ja kohopiima kupatus”. Ei ole ma mingi hapatus ega kupatus. Kui olen tšuhkna, siis olen (ibid lk 2).

\section{Moraaliõpetus regilaulude kaudu}

Lapsepõlves sai Laine Mägi tädi Almat ja vanaema Juuli-Mariet kuulates selgeks mitmeid rahvalaule, mille nemad olid omakorda pärinud oma esiemadelt. Lapsel tekkis eriline kontakt just regilauludega, mis sisaldasid rohkem salapära kui muu õpitu. Turvalises koduses keskkonnas omandatud mõtisklevad meloodiad, murdekeelsed sõnad, paeluvad süžeed ja õpetuslik sisu moodustasid omamoodi elamusliku terviku. Regilaule nimetas Laine Mägi vanadeks lauludeks. Samuti seostas ta laule isikutega, kellelt lugu õpitud, öeldes nende kohta kas vanaema või Alma-tädi laulud.

Laine Mägi isaema Juuli-Marie Lepla, neiupõlvenimega Jäär (vt foto 1), sündis 1879. aastal Vastseliina kihelkonnas Viitkal ja suri 1970. aastal samuti Vastseliinas. Informandi lapsepõlves elas vanaema koos nende perega Petserimaal Ruuda külas.

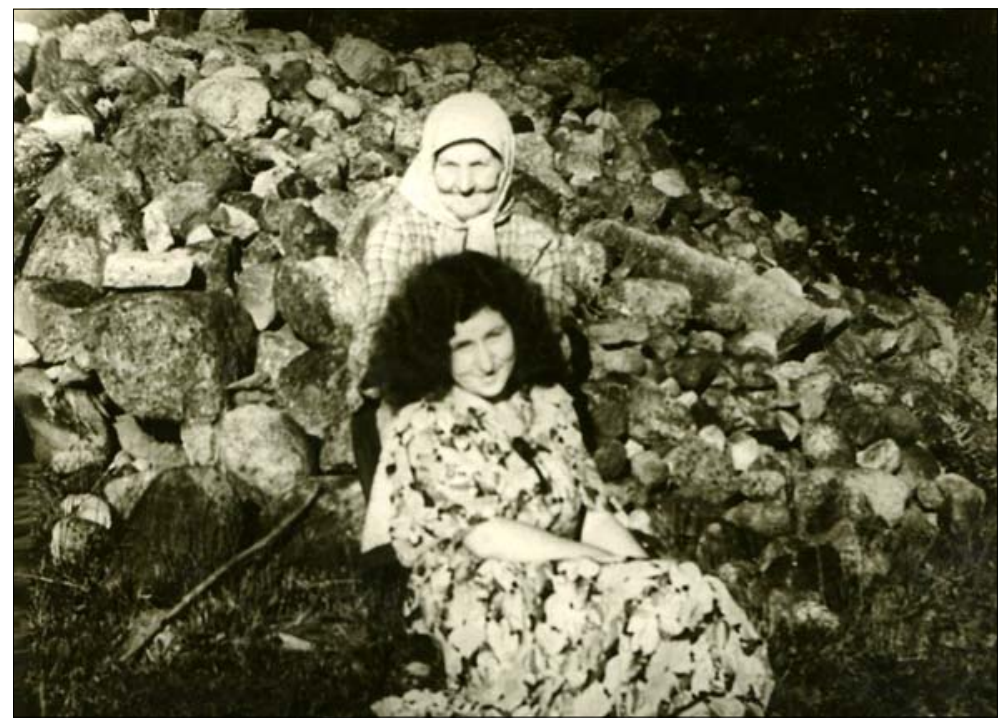

Foto 1. Laine Mägi vanaema Juuli-Marie Leplaga 1950. aastatel. Foto Laine Mägi erakogust. 


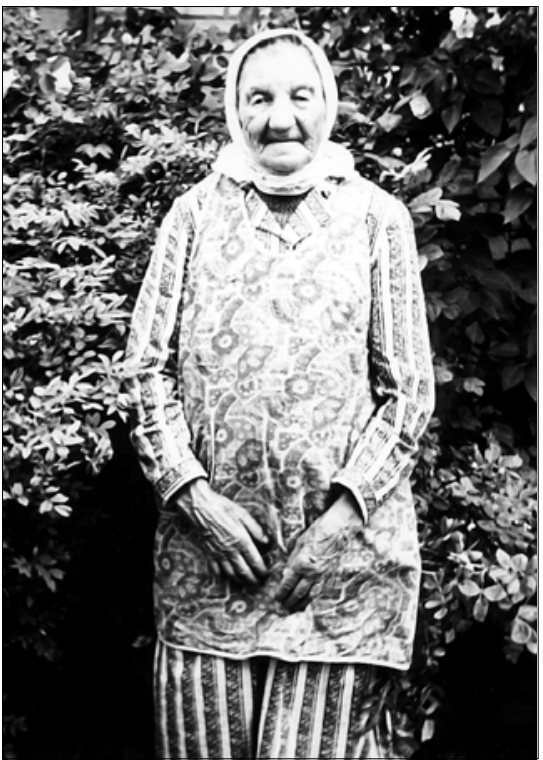

Foto 2. Alma Kübar (Kikkas) 1970. aastate lõpul Vastseliinas. Foto Laine Mägi erakogust.

Laine ema õde Alma Kübar, neiupõlvenimega Kikkas (vt foto 2), sündis 1897. aastal Rõuge kihelkonnas ja suri 1981. aastal Vastseliinas. Kuna tema isa oli käsitööline, liikus pere mõisates tööd tehes mööda Kagu-Eestit ringi. Alma naasis abielludes Rõuge kihelkonda Ruusmäele, kus elas suure osa oma elust. Lesena tuli ta 1930. aastail Ruuda külla õe pere juurde elama.

Vanemad tegid tööd ning vanaema ja tädi hoidsid lapsi. Huvitav on see, et Lainest neli aastat vanem õde Leida (vt foto 3 ) ei mäleta kuigi hästi hoidjate õpetusi ja laule. Seda tõenäoliselt sellepärast, et vanemad võtsid ta juba tööle ja ka pidudele kaasa, samas kui noorem tütar jäeti koju hoida:

Sugulased elasid meil väljaspool Petserimaad, peamiselt Vastseliina ja Rõuge kandis. Kui neile külla mindi, kutsuti Alma-tädi koduhoidjaks. Õde oli vanem, õde võeti külla kaasa. Mina jäin koju. Ja siis lõi Alma-

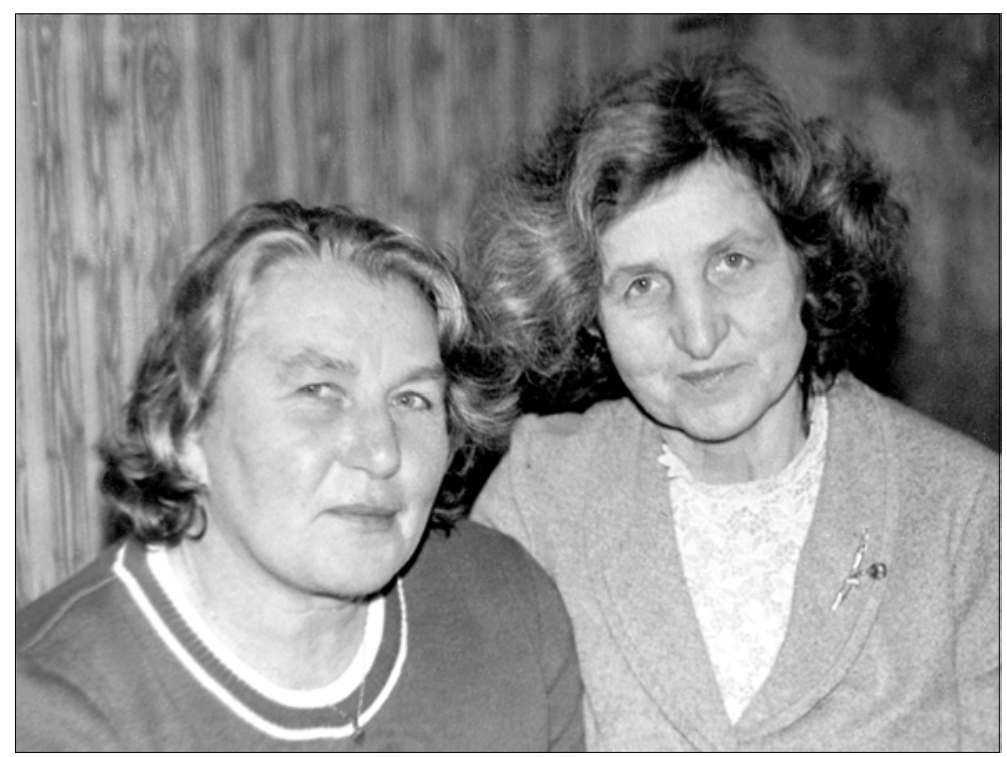

Foto 3. Õed Leida ja Laine 1980. aastatel. Foto Laine Mägi erakogust. 
tädi oma lauluregistrid lahti. Ja nii ma õppisin tädilt vanu laule. Tädi oli hea laulja ja laulude pagas oli suur. Minu isapoolne vanaisa GustavEduard ütles ikka, kui tädi meile Ruuta tuli, et köster tuli (Laine Mägi, käsikiri 15. 09. 2006 Kärdla, lk 2).

Aga laulmine ei olnud pelgalt lõbu. Regilaule laulsid vanaema ja Alma lastele ilmaasjade seletamiseks ja väärikate elukommete õpetamiseks. Igal laulul oli oma lugu ja moraal:

Tädi laulis palju ja ka kogu aeg seletas, mis need laulud tähendasid (ibid $\operatorname{lk} 3)$.

Vanad laulud olid lapsele põnevad. Näiteks laul "Veli ai ussõ" (vt noodistus 1) rääkis sugulaste poolt põlatud tütarlapsest. Laulu moraal selgitas, et ühe pere lapsed peavad omavahel hästi läbi saama. Kogu suguvõsale oleks suureks häbiks, kui juhtuks nii nagu laulus, kus veli ajab õe kodust välja.

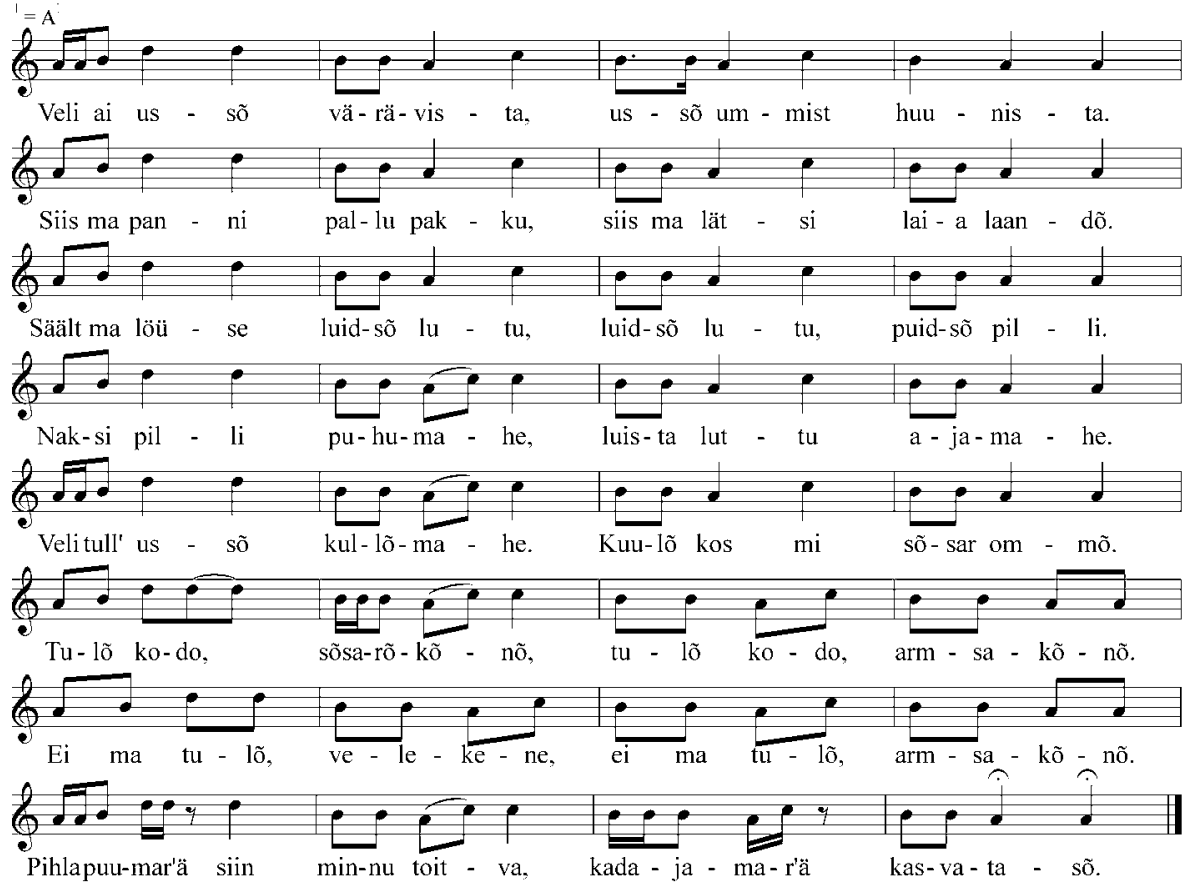

Noodistus 1. ERA, DV 426 (1). "Veli ai ussõ”. Laine Mägi 31. 03. 2005 Hiiumaa, Kärdla. Salvestanud Sulev Keedus, noodistanud ja litereerinud Helen Kõmmus. 
Laulu "Vanamiis minno kose" (vt litereering 1) kokkuvõtteks olevat tädi öelnud, et paremp om ellä vana var'on kui noore ilon (ibid lk 5).

Va-na-/ mi-is / min-no/ ko-se, ha-bõ-/ mis-ta / hau-ga-/ tõ-li.

il-los / tüt-rek, / val-lus / tüt-rek, mis sul/vi-ga/ mul-lõ / tul-la, mul om / mu-r'o/ mul-lust / lei-bä, koo-rik/ om viil/ kol-mõ / aas-tast.

Litereering 1: "Vanamiis minno kose”. Laine Mägi käsikiri 31. 03. 2005 Hiiumaa, Kärdla. Informandi kirjaviis muutmata. Materjal autori valduses.

Vanaema Juuli-Marielt kuuldud laulu "Väikene olli" (vt noodistus 2) õpetusivaks oli kohustus hoolitseda vaeste ja väetite eest. Loomulikult rõhutas lugu ka seda, et emaarm on suurim ja asendamatu. Laulu kaudu jagatud mõtted olid nii olulised, et lauldes olid vanaemal tihti pisarad silmis ja ta pühkis silmi põlleservaga (ibid lk 4).

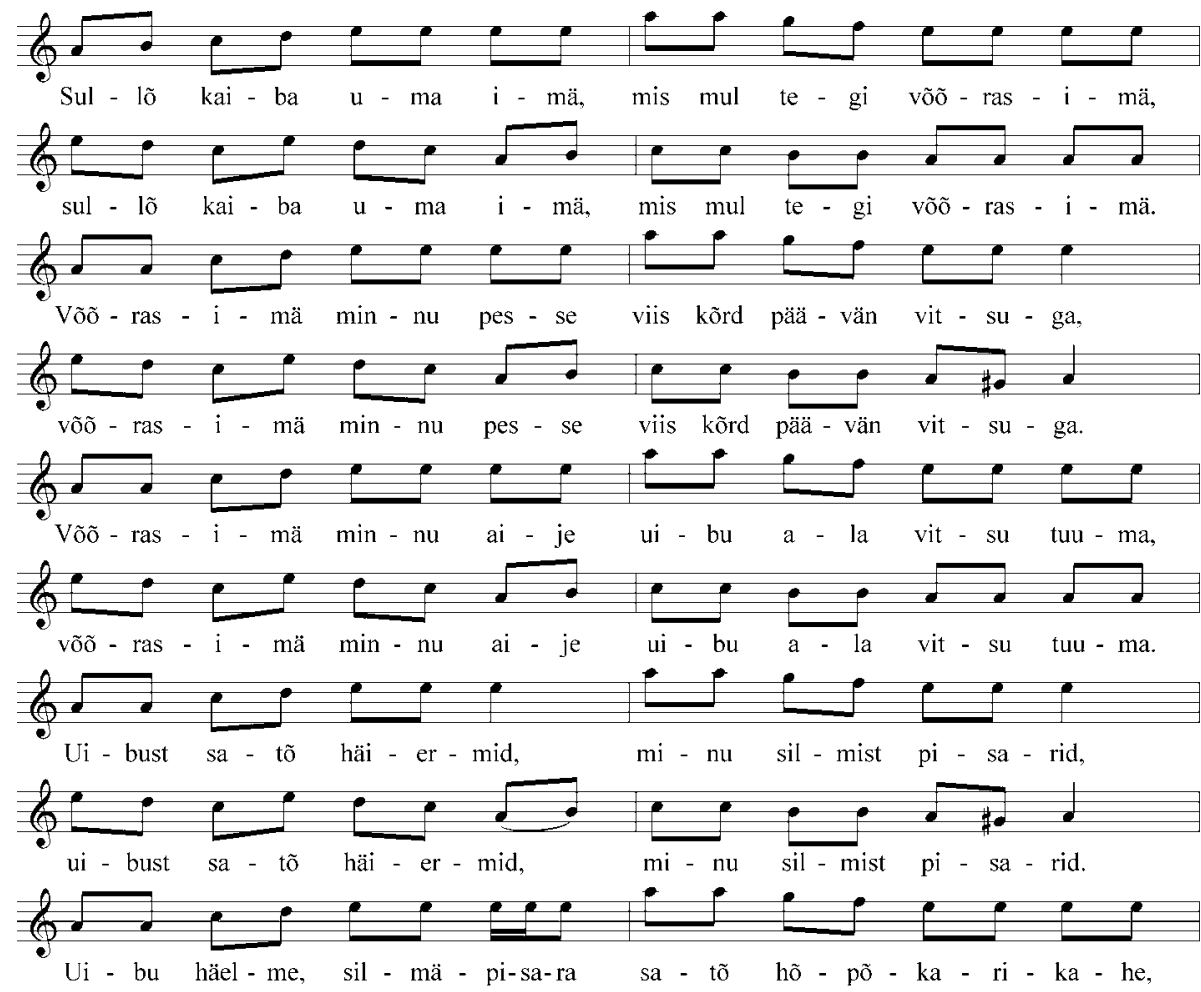




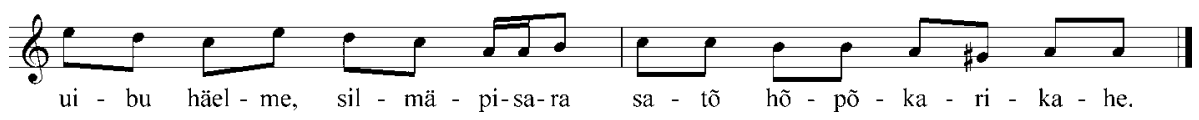

Noodistus 2. ERA, DV 426 (2). "Väikene olli". Laine Mägi 31. 03. 2005 Hiiumaa, Kärdla. Salvestanud Sulev Keedus, noodistanud ja litereerinud Helen Kõmmus.

\section{Kolme regilaulu sisust ja vormist}

Kolm Laine Mägi lauluvarasse kuuluvat võrukeelset regilaulu pakuvad huvitavaid vormilisi ja sisulisi leide.

Laulu "Veli ai ussõ" (vt noodistus 1) süžee on järgmine: Venna poolt kodust välja aetud õde põgeneb metsa, leiab sealt vilepilli ja hakkab mängima. Vend kuuleb õe mängu ja kutsub teda koju tagasi. Ent õde keeldub ning jääb metsa pihlapuu ja kadaka toita.

"Veli ai ussõ" liigitub ülemaaliselt tuntud ja populaarse laulutüübi "Põlatud laps" alla (Tedre 1974: 186). Tihti (ja ka antud laulu puhul) kontamineerub see laulutüübiga "Sarvepuhuja", mis on levinud peamiselt Lõuna-Eestis (Tedre 1974: 136).

Vormiliselt on regilaulu värsiread reeglipärased ja püsivad 8-silbilises struktuuris. Tekst grupeerub selgelt paralleelvärsirühmadeks. Ühe vormitunnisena on läbivalt esindatud alliteratsioon.

Näiteks:

Siis ma /pan-ni/ pal-lu/pakku, siis ma / lät-si / lai-a / laan-dõ.

Säält ma / lö̈̈d-se / luid-sõ / lu-tu,

luid-sõ / lu-tu, / puid-sõ / pil-li.

Nak-si/ pil-li/ pu-hu/ -ma-he,

luis-ta/ lut-tu/a-ja/-ma-he.

Lõuna-Eesti regilaulude vanemad viisid ei ületa tavaliselt kvarti, meloodia kulg on astmeline või väikeste hüpetega (Tampere 1999: 45-46). Laine Mägi lauldud "Veli ai ussõ" kaherealine viis on vanemale rahvalaulukihistusele omaselt kitsa heliulatusega, meloodiajoon on voolav st suuremate intervallihüpeteta.

Eesti Rahvaluule Arhiivis leidub 84 sellele laulutüübile vastavat tekstivarianti. Neist 16 tekstil on uuritava lauluga sarnane ülesehitus ja kontaminatsioonid. Kõik on kogutud Lõuna-Eestist: 4 Võrumaalt (3 Karulast, 1 Urvastest), 6 Tartumaalt (2 Tartu-Maarjast, 2 Sangastest, 1 Äksist, 1 Palamuselt) ja 6 Mulgimaalt (2 Helmest, 2 Paistust, 1 Tarvastust, 1 Viljandist). Leidus ka üks identne viis Rõuge kihelkonnast). 
Laulus "Vanamiis minno kose" (vt litereering 1) on läbivaks eaka kosilase meelitav kutse väljavalitule, millele järgnevad lubadused ühes enesekiitusega. Tegu on kogu Eestis tuntud kosjalauluga, mis mahub Lõuna-Eestis tuntud laulutüübi "Ilus neiu, tule mulle" alla (Tedre 1974: 275-277).

Retsiteeritud regilaul on nii värsimõõdult kui ka värsijalgade kvantiteedilt reeglipärane. Teksti lühidusest hoolimata on säilinud paralleelvärsirühmi. Samuti esineb laulutekstis läbiv alliteratsioon.

Näiteks:

\section{Mul om / mu-r'o / mul-lust / lei-bä, koo-rik/ om viil/ kol-mõ / aas-tast.}

Eesti Rahvaluule Arhiivi kogudes leidus 12 Laine Mägi esitatud lauluga sama tekstitüübi alla kuuluvat ja sarnase ülesehitusega teksti. Lauluvariandid olid enamikus kogutud Lõuna-Eestist: 2 Võrumaalt (1 Rõugest, 1 Harglast), 3 Mulgimaalt (2 Tarvastust, 1 Viljandist), 5 Tartumaalt (2 Tartu-Maarjast, 1 Palamuselt, 1 Rõngust, 1 Võnnust), 1 Pärnumaalt (Vändrast) ja 1 Järvamaalt (Türist).

Laulu "Väikene olli" (vt noodistus 2) sisuline arendus on järgmine: Varakult orvuks jäänud laps leiab karjas käies ema kalmu ja kutsub surnut hauast üles tõusma. Leinaja kurdab kurja võõrasema üle, räägib õunapuust peksuvitsade võtmisest ja võrdleb õunapuuõisi hõbekarikasse langevate vaeslapse pisaratega.

Antud laulu puhul on tegu siirdevormilise regilauluga. Loo tekst on kontaminatsioon mitmest laulutüübist: "Ema haual", "Ema ja armud", "Võõralt vitsa, omalt leiba" (Tedre 1974: 221-222). Selles loos ei ole regivärsi kvantiteedireeglid nii hästi säilinud kui eelmistes lauludes. Vormiliselt leidub 8-silbiliste regivärsside seas 7 -silbilisi, kus viimase rõhurühma täidab 3-silbilise sõna lõpusilp.

Näiteks:

\section{Ui-bust/ sa-tõ / häi-er- / mid, Ø mi-nu/sil-mist/ pi-sa-/rid. Ø}

Alliteratsioon pole nii läbiv kui näiteks "Veli ai ussõ" laulus, ent esineb siiski. Näteks:

$$
\begin{aligned}
& \text { Mus-ta / mul-la / mät-tä / a-la, } \\
& \text { val-gõ / lii-va / val-li / a-la. }
\end{aligned}
$$

Laulus, eriti selle lõpuosas on suhteliselt vähe paralleelvärsirühmi.

Maks Goldin esitab eesti ja läti rahvamuusika suhteid valgustavas artiklis tähelepaneku, et kogu Lätis tuntud vaeslapselaulu viis on sealt levinud Lõuna-Eestisse, kus sellest on talletatud erinevaid lokaalseid variante (Goldin 1977: 124-125). Meil lauldud meloodial on uuema lõppriimilise laulu tunnused, näiteks lai heliulatus ja suured intervallihüpped (Rüütel \& Kokamägi 1964: 35). 
Ühtekokku oli Eesti Rahvaluule Arhiivi kogudes 17 selle laulutüübi alla kuuluvat ja sarnase kontaminatsoonilise ülesehitusega teksti, kõik Võrumaalt: 6 Rõugest, 6 Põlvast, 3 Harglast, 1 Vastseliinast ja 1 Kanepist. Informandilt kuuldud vaeslapselauluga sarnaseid viise on talletatud kogu Lõuna-Eestist. Eesti Rahvaluule Arhiivis leidus selle laulu 10 viisivarianti, neist 9 Võrumaalt (3 Vastseliinast, 2 Rõugest, 2 Harglast, 1 Urvastest, 1 Kanepist) ja üks Tartumaalt (Puhjast).

\section{Emakeel ja laulukeel}

Laine Mägi on pärit keskkonnast, kus oli paralleelselt kasutusel neli kõnepruuki. Lapsena elas ta võru ja setu murdekeeleruumis, ${ }^{3}$ kooliajal Petseris lisandusid eesti kirjakeel ja vene keel. Siia võib lisada veel Hiiumaale tulles kogetud hiiu murrakud. ${ }^{4}$ Seega on mõistetav, et eesti ühiskeel on temale kujunenud kõiki erinevaid kõnepruuke ühendavaks suhtluskeeleks.

Informandi laulukeel ehk laulutekstides põimuv murde- ja kirjakeel pakub põnevat uurimisainest. ${ }^{5}$ Vanemates lauludes on esitaja emakeel, võru keel, üsna traditsiooniline. Tema regilauludes on läbiv idavõru kõnepruuk, valdav on Vastseliina alal kõneldud võru murre, kus esineb ka läänevõru keele-elemente. Need vormid on tõenäoliselt pärit ema õelt, Rõuge kihelkonnas elanud Alma-tädilt. Näiteks võib tuua $n$-inessiivi (mõtsan) ja $u$-lõpu ( $k o k k u)$. Tema regilauludes leidub vanu keelendeid, mida tänapäeval räägitavas murdekeeles harva ette tuleb, näiteks vormel värsis veli ai ussõ ('ajas välja'). Võrukeelsete laulude esitamisel ja sõnade kirjutamisel järgib informant üsna järjekindlalt vokaalharmooniat. Ent tuleb märkida, et laulja on mõnede sõnakujude kasutamisel ebajärjekindel.

Näiteks:

\section{Ui-bust / sa-tõ / häi-er-/mid; [---] \\ Ui-bu / häel-me, /sil-mä- / pisa-ra. ${ }^{6}$}

Tegu on erinevates Võrumaa piirkondades kasutatud samatähenduslike vormidega. Nende kõrvuti kasutamine viitab taas kord lauliku võrukeelse tausta mitmekesisusele.

Lõppriimiliste laulude tekstid on juba sümbioos eesti ühiskeelest ja võru keelest. Uuemates lauludes on Laine Mägi võru keel juba tuntavate eesti kirjakeele mõjudega, näiteks tegusõna lõpp -n (laulan), $s$-inessiiv (mõisas) jms. Eesti ühiskeele mõju võib pidada loomulikuks, arvestades, et informant on olnud ligi 50 aastat võru keeleruumist eemal.

On tähelepanuväärne, et setude asualal Petserimaal asunud võru külast pärit lauliku regilaulutekstides ei ole setu kõnepruugile iseloomulikke jooni. 
Informandi mälestuste järgi oli piirkonna ainsa võrukeste küla ja setu noorte läbikäimine tihe. Suhtluskeeleks kujunes vastavalt suurema grupi ehk setude emakeel.

Võru ja setu kõnekeele vahetegemist mäletab Laine Mägi ühest perekondlikust vahejuhtumist 1930. aastate lõpul. Nimelt riivas ema kõrva tütre keelde siginenud sõnalõpuline $h$, mis nende koduses võru keeles oli $n$ (võru mõtsan, setu mõtsah) ja laps sai setu keele purssimise pärast kõvasti noomida. See, et informandile tuttava setu kõnepruugi iseärasused ei mugandunud tema võru esiemadelt õpitud laulukeelde, viitab omandatud lauluvara pärinemisele pikkade traditsioonidega ja konservatiivsest võru rahvakultuurist.

\section{Kokkuvõtteks: kristalliseerunud regilaul}

Vaadeldud kolme laulu puhul on tegu mitmekülgse ja huvitava pärimusega. Kahe regilaulu, "Veli ai ussõ" ja "Vanamiis minno kose" tekstid on regilaulule reeglipärase värsimõõdu (8-silbiline värsirida, silpide kvantiteet) ja vormilise ülesehitusega (paralleelvärsirühmad, alliteratsioon). "Veli ai ussõ" viis vastab 2-realise regilauluviisi kriteeriumidele. Kolmanda laulu "Väikene olli" tekst on siirdevormiline. Värsimõõdu, paralleelvärsirühmade ja alliteratsiooni puhul on tavapärase regilaulutekstiga võrreldes juba ebareeglipärasusi. Viis ühendab endas regilaulu ja riimilise rahvalaulu meloodikat. Vanemate ja uuemate laulutekstide keel, mis sisaldab nii erinevate võru piirkondade kõnelemistavasid kui ka eesti kirjakeele jooni, on oma mitmekihilisuse tõttu uurimisväärne materjal. Keel ongi informandile üks olulisi identiteedimarkereid. Juba üle poole sajandi Hiiumaal elanuna on ta oma võru meelsust ja keelsust säilitanud esiemadelt päritud laulude abil.

Kokkuvõtteks võib öelda, et Laine Mägi vahendusel on meieni jõudnud hulk tähelepanuväärset rahvaluuleainest, mis esindab nii vanemat kui ka uuemat Lõuna-Eesti laulutraditsiooni. Ühe võimaliku vastuse küsimusele, kuidas on rahvalaulud informandi pärimusmälus nii hästi säilinud, võiks anda geograafiline ja ajaline distants võrukeelsest kultuurist, mis omamoodi soodustas lapsepõlves õpitu kinnistumist. Ajas ja ruumis kaugele jäänud mälestused kristalliseerusid uue kultuurikeskkonnaga vastamisi sattudes.

Välitööde käigus kogesin taas, kui innustav on nii koguja kui ka informandi mõlemapoolne huvi pärimuse edasiandmise protsessi vastu. Võru lauliku siiras soov jäädvustada oma esiemadelt päritu tulevastele põlvedele ärgitas teda sisukale koostööle rahvaluulekogujatega.

Lõpetuseks sobib mõte Laine Mägi eluloost, kus ta toonitab lapsepõlves saadud veendumust muusika ja elu lahutamatusest: 
Olid pulmad või leeripeod - lauldi nii, et "lagi kerkis". Sugulastel meil käies oli ikka külakostiks laul. Sõda tegi muidugi omad karmid korrektiivid, kadusid mitmedki lähedased, elud paisati segi. Kuid laul ei surnud. Nad muutsid küll oma sisu, kuid nad jäid inimeste juurde ja käisid varjuna neil kaasas. Laul oli vajalik (Laine Mägi, käsikiri 15. 09. 2006 Kärdla, lk 3).

\section{Kommentaarid}

1 Välja arvatud Kihnu ja Setumaa, kus traditsiooniline laulukultuur on veel elujõuline.

${ }^{2}$ Vaata kogude nimekirja artikli lõpus.

3 Umbes 70000 kõnelejaga võru keel on üks lõunaeesti keeltest (murretest), mis on levinud põhiliselt Kagu-Eestis, ajaloolise Võrumaa alal ning hõlmab praegust Võru ja Põlva, osalt ka Tartu ja Valga maakonda (Karula, Hargla, Urvaste, Rõuge, Kanepi, Põlva, Räpina ja Vastseliina kihelkond). Üpris palju võru keele oskajaid leidub tänapäeval ka Tartus, Tallinnas ja mujal Eestis (vt Pajusalu jt 2000; Kasak 1998).

${ }^{4}$ Hiiumaa nelja kihelkonna - Pühalepa, Käina, Reigi ja Emmaste - murrakute vahel on tähelepanuväärseid häälduserinevusi (vt Lonn \& Niit 2002).

5 Keeleanalüüsil sain konsultatsiooni Võru Instituudi teadurilt Sulev Ivalt. Vt ka Keem 1997.

${ }^{6}$ häierm, -ä, -ät = hä(i)elm - õis (Võru-Eesti sõnaraamat, http://www.folklore.ee/ Synaraamat -8 . aprill 2009).

\section{Kogude nimekiri}

Laine Mägi, helisalvestus (2 h) 1. 11. 2004 Kärdla. Sisu: 1 regilaul, 10 uuemat rahvalaulu, 2 tantsukirjeldust, 3 naljandit, mälestused. Salvestanud Helen Kõmmus. Materjal autori valduses.

Laine Mägi, käsikiri (2 lk) 31. 03. 2005 Kärdla. Sisu: 2 regilaulu, tekstid koos kommentaaridega. Materjal autori valduses.

Laine Mägi, videosalvestus (2 h) 31. 03. 2005 Kärdla. Sisu: 2 regilaulu ja 13 uuemat rahvalaulu koos kommentaaridega, 2 naljandit, mälestused. Salvestanud Sulev Keedus. (Vt ka ERA, DV 426).

Laine Mägi, käsikiri (2 lk). 8. 01. 2006 Kärdla. Sisu: 2 regilaulu, tekstid koos kommentaaridega. Materjal autori valduses.

Laine Mägi, käsikiri (19 lk). 15. 09. 2006 Kärdla. Sisu: 2 regilaulu, 9 uuemat rahvalaulu, 1 lastelaul, 2 omaloomingulist laulu, tekstid koos kommentaaridega, elulugu, mälestused. Materjal autori valduses.

Laine Mägi, helisalvestus (1,5 h). 7. 10. 2006 Kärdla. Sisu: noorpõlvemälestused. Salvestanud Helen Kõmmus. Materjal autori valduses.

Laine Mägi. 12 fotot sugulastest ja Ruuda küla eluolust 1932-2006. Skaneeritud oktoobris 2006. Materjal autori valduses. 


\section{Kirjandus}

Goldin, Maks 1977. Läti ja eesti rahvamuusika suhetest (vene keeles). Ingrid Rüütel (koost ja toim). Soome-ugri rahvaste muusikapärandist. Tallinn: Eesti Raamat, lk 124125 .

Kasak, Enn 1998. Võru murre ja võro keel. Õdagumeresoomõ väikuq keeleq. Võro Instituudi toimõndusõq 4. Võro, lk 13-19.

Keem, Hella 1997. Võru keel. Eesti Teaduste Akadeemia Emakeele Selts. Võru Instituut. Tallinn: Eesti TA Emakeele Selts.

Lonn, Varje \& Niit, Ellen (koost) 2002. Saarte murde tekstid. Eesti murded VII. Tallinn: Eesti Keele Sihtasutus.

Pajusalu, Karl \& Koreinik, Kadri \& Rahman, Jan 2000. Lõunaeesti keele kasutusest Kagu-Eestis. A kiilt rahvas kynõlõs... Võrokeste keelest, kommetest, identiteedist. Võro Instituudi toimõtiseq. Võro: Võro Instituut, lk 13-37.

Rüütel, Ingrid \& Kokamägi, Hilja (koost) 1964. Laul olgu lühike või pikk... Valimik ajaloolisi sündmusi ja ühiskondlikke vahekordi kajastavaid eesti uuemaid rahvalaule. Tallinn: Eesti Riiklik Kirjastus.

Tampere, Herbert (koost) 1999 (1. trükk 1935). Ingrid Rüütel (toim). Eesti rahvaviiside antoloogia I. Tallinn: Eesti Keele Instituut.

Tedre, Ülo (koost) 1974. Eesti rahvalaulud IV. Antoloogia. Tallinn: Eesti Raamat.

\section{Summary}

\section{"There I Found a Bone Pipe": On the Folk Songs and Self-Identification of Laine Mägi}

Helen Kõmmus

Key words: folk song, folklore collection, regilaul or Kalevala-metric folk song, Võru culture, Võru language

The article discusses written and video material recorded from Laine Mägi, a folklore informant who was born in Võru County, South Estonia, but is living on the island of Hiiumaa. The materials were recorded during the folklore collection on the islandi $n$ 2004-2007. The collected materials include fifteen Kalevala-metric end-rhymed folk songs (regilaul) in dialect and literary language. A more detailed discussion involves three Kalevala-metric folk songs in Võru dialect: "Veli ai ussõ" ['Brother Drove Me out'], a song about family relationships, "Vanamiis minno kose" ['An Old Man Proposed Marriage to Me'], a song about proposing marriage, and "Väikene olli" ['When I Was Young'], a song about orphanhood. These three songs are analysed from the angle of formal rules and dialectal language, and the collected material is discussed from the aspect of the performer's biography and the social context. 